The Effect of Learning Abroad on the Students' Career Direction and Employability through AustralianIndonesian Student Mobility Programs

\author{
Alam Nasrah Ikhlas ${ }^{1^{*}}$ \\ ${ }^{1}$ Deakin University, Australia \\ *Correspondence: aikhlas@deakin.edu.au
}

\begin{abstract}
Among key features of the internationalization of higher education, student mobility has been given a big attention by universities and relevant stakeholder to achieve advance knowledge, intercultural skills, intellectual capital, and prospective labour market benefit. The long-standing flow of Indonesian students to Australia and now Australian students travel outbound to Indonesia through the New Colombo Plan (NCP) indicate the development of student mobility collaboration between both nations. Yet, little is known about the effects of student mobility program on the students' career direction and employability. Using Bourdieu's thinking tools of capital, habitus, field, and social reproduction, this article is aimed to address this gap by examining the perspectives of participating students and other relevant stakeholders. Findings generated from this research will be beneficial to higher education institutions (HEIs) and policy makers in Indonesia and Australia so that all parties involved can acquire expected outcomes of this student mobility program.

Keywords: student mobility, learning abroad, international student mobility in Indonesia, the New Colombo Plan, Bourdieu, career direction and employability
\end{abstract}

\title{
Introduction
}

It is not difficult to find empirical research and literature concerning the benefits gained by students from their international experience through participating in student mobility programs. Personal, cultural, and career/employment outcomes are some benefits that can be obtained from the

Received October 9, 2020; revised December 13, 2020, and December 28, 2020; accepted January 29, 2021; electronically published January 31, 2021

Journal of Comparative \& International Higher Education

December, 2020, Vol. 12, No. 6S1, pp. 112-121.

DOI: $10.32674 /$ jcihe.v12i6S1.3086

(C) 2020 Journal of Comparative \& International Higher Education. All rights reserved. 
programs (Roy et al. 2019). Studies on international student mobility have highlighted that knowledge exchange, academic collaboration, quality improvement, developing mutual understanding as well as increasing language and cultural skills are some of the vital significances and rationales for encouraging international student mobility (Wadhwa, 2018). However, little is known about how international student mobility affects students' career direction and employability, particularly in the context of developing countries in which Indonesia is viewed. Meanwhile, it has been revealed that the participation rate of Australian students in (outbound) international student mobility is relatively low due to several barriers like curriculum restrictions, costs, unsatisfying supports, work commitments, family, and safety concerns (Trilokekar \& Rasmi, 2011; Jones et al., 2016). Hence, Australian government and HEls have made employability as a central attention in undertaking policies and strategies to increase their student's participation in international mobility. UNESCO Institute for Statistics (2020) recorded 12,180 Indonesian student went to Australia for studying at tertiary education level and put Australia at the top of the list of most popular destination for Indonesian students. On the other hand, in order to strengthen Australia's position and influence in the Indo-Pacific region, the Australian government's foreign policy agenda then encouraged the involvement of its students through student mobility as public diplomacy, which ultimately brings forward Australian economic diplomacy (Byrne, 2016). Given this objective, in 2013, Julie Bishop, Australia's Minister of Foreign Affairs (2013-2018), initiated the New Colombo Plan (NCP), and it became her signature legacy after NCP officially introduced in 2014 by the Federal Government. Indonesia thus became one of the destination countries for Australian students to participate in international student mobility program under the New Colombo Plan (NCP) and in 2014 Indonesia was one of four pilot locations for the NCP students to study and engage in work placements (Department of Foreign Affairs and Trade, 2020).

Given the facts, it is quite surprising to know that very little attention is paid to examining the outcomes of the student mobility program between Indonesia and Australia, particularly in terms of 
graduates' career direction and employability. In fact, overall, studies on the implementation and development of student mobility programs in the context of cooperation between Indonesia and Australia are also very limited, thus how important Indonesian student mobility programs to Australia at the institutional and national levels in Indonesia are still questioned. This research will investigate this phenomenon and the findings generated will contribute to the better implementation and development of Indonesian student mobility programs to Australia for students, institutions and governments.

Therefore, the overall research arrangement is therefore articulated into two research questions:

- How does the learning abroad experience affect the students' and graduates' career direction and employability as perceived by students, graduates, mobility staff, policy makers, and employers?

- $\quad$ How do the field, capital, and habitus interplay and affect the students' and graduates' career direction and employability?

This research mainly uses the term learning abroad to outline an educational experience in which a student utilizes a certain duration of time engaging in an academic activity in another country yet remains formally registered at an institution in the country of origin, which is also known as intradegree mobility (Potts, 2015; Gribble \& Tran, 2016). In several contexts, the use of learning abroad term can also be called outbound mobility, study abroad, student exchange, or international learning mobility (Potts, 2015). The reason for using and focusing on learning abroad is due to its inclusivity in encompassing studying overseas, internships, international work experience, practicum assignment, community service, volunteering, and other learning efforts where participating students are still enrolled during their study in a foreign country (Potts, 2016). In addition, the learning abroad program is more feasible to examine than a full degree program, considering the very small number of Australian students that went to Indonesia to obtain a degree. 


\section{Research Methodology}

To address the research questions and gain deeper insight into the effect of learning abroad on students' career direction and employability through Australian-Indonesian student mobility programs, this research conducts case study design along with interview for data collection. This research will also be conducted using comparative multiple-case study. To avoid answering a question which is too broad or a topic with many objectives for one research, placing boundaries on a case is important to prevent the outburst from occurring (Stake, 1995; Yin, 2009). In this research, binding the case is based on definition and context (Miles \& Huberman, 2014). The case is primarily bounded to the examination of how the participating students and graduates perceive learning abroad experience in Australian and Indonesia affects their career direction and employability. However, in order to gain comprehensive insight about related topic, the case is further divided into sub-cases or sub-unit of analysis as follows: how the mobility staff in the university, the policy makers, and the employers perceive the effect of learning abroad experience on students' career direction and employability. Therefore, perspective from each stakeholder will also lead to finding similarities and differences towards the effect of learning abroad program on students' career direction and employability in Indonesia and Australia so that strategies can be formulated by university and government of each country for better organization of the program between the two countries.

In order to analyse the data gained from the interviews, this research will use six phases of thematic analysis concept by Braun and Clarke (2006). In order to assure the validity and reliability of the emerging patterns or themes, this research will combine computer software-based and manual coding. NVivo program is chosen to record and analyse the findings generated. Besides, a visual way of coding will also be conducted for the manual coding. As the material have been coded and categorized in NVivo program. Every digital transcript will be read again and then important sections according to codes that emerge which are relevant to my research questions will be highlighted. This is the process 
by which data or code material will be pared and sorted to identify similarities in phrases, relationships between variables, patterns or themes. All of the sections that have been highlighted will be transferred to new documents under each code.

\section{Analysis Using Bourdieu's Theoretical Framework}

Drawing on Pierre Bourdieu's (1990) thinking tools formulated in his theory of social practice, especially the habitus and cultural capital within cultural and social reproduction, further analysis of this research reveals the comprehension of the students' and relevant stakeholders' perspectives and engagement in, and outcomes of learning abroad programme.

To date, the approach through the concept of cultural and social reproduction put forward by Bourdieu is favoured by a number of scholars to analyse international student mobility. Through Bourdieusian perspectives, academics discuss that international student mobility is carried out in exchange for social and cultural advantages. For example, Dall'Alba and Sidhu (2015) argue that participating students can acquire intercultural competences, cosmopolitan perspectives, and advantage in potential employment market. Similarly, Dai, Lingard and Musofer (2020) outline that modified habitus will enable international students to find a place in the global labour markets. Tran (2016) also highlights that international student can obtain new experiences and outlooks as an investment to determine their 'becoming'.

Within the fields of Indonesian and Australian international student mobility programs, and especially career direction and employability of participating students, there is both effort and contest in obtaining positions and resources; it becomes interesting to see how the agencies involved in these fields compete with each other with their respective habitus and fields. Based on Bourdieu's ideas, international student mobility can be interpreted as a form of interaction between the diverse social, cultural and economic structures that manage the field of international education and incorporate different forms of capital and aspirations of participating students (Tran, 2016). 


\section{Findings of the Research}

A preliminary analysis of data collection on research participants identified that positive responses generated by learning abroad experiences. The four main themes that dominate participants' answers when asked directly about the effect of their learning abroad experience on the students' career direction and employability are foreign language acquisition, networking, global perspective/intercultural understanding, and communication skills. Most of the participants point out that the experience of studying abroad provides benefits for students and graduates to get a job. It turns out that the experience of engaging in a culturally different environment and how to solve problems abroad alone and independently have a considerable impact on self-capacity building after completing the program. The duration and design of the program also determine how big the effect of learning abroad experience on the (early) career direction of the students and graduates. At this stage, it has been noticed that the longer the duration of the international student mobility program, the clearer the career trajectory perceived by participating students.

\section{Significance of the Research}

There is no doubt that student mobility has been acknowledged as an important way to support national goals to develop human capital and strengthen diplomatic, economic and cultural connection with other countries across the world (Tran \& Vu, 2018), as well as almost all stakeholders agree with the assumption that learning abroad or participating in international student mobility program—degree or non-degree program — will have a positive effect on students. However, questions increasingly arise on how international education and experience can fulfil the students' objectives and expectations to be fit in professional world and their career direction in the context of unpredictably labour market and policy changes at the greater national and international level (Blackmore et al., 2017). Moreover, with the increasing advancement of recent technology, the development of learning methods such as distance/e-learning make some people start asking whether it is still necessary to learn abroad where 
access to information is currently only as wide as a human's palm? What makes learning abroad or intradegree mobility program still relevant?

Accordingly, the findings from this research contributes to the development of existing notion or hypotheses that learning abroad and international student mobility program can foster students' and graduates' cultural awareness, cross-cultural understanding, global citizenship, and other important soft skill which enhance their career direction and employability eventually, particularly in the context of developing country like Indonesia.

It is also important to notice that in broader aspect, developing further analysis on how these learning abroad outcomes can support the career direction and employability of participating students, can contribute to the practices and policies of international student mobility programs development at both the institutional and national level. Hence, this research contributes to constructing policies or practices undertaken by government and HEls in order to develop student mobility program, attract international students, and nourish those high-prospective talents to be globally competitive, so that rationale for promoting learning abroad among scholars, faculties and policy makers can be invigorated.

\section{Author Note}

Alam Nasrah Ikhlas, is a Ph.D. student at the School of Education, Deakin University. He works at the Ministry of Education and Culture of Indonesia as a Senior Policy Analyst of Educational Learning. He was also the division head of recognition of prior learning and coordinator of student mobility program as well as international collaboration for Indonesian higher education institutions. His research focuses on the outcomes of student mobility program between Australia and Indonesia. 


\section{References}

Blackmore, J., Gribble, C., \& Rahimi, M. (2017). International education, the formation of capital and graduate employment: Chinese accounting graduates' experiences of the Australian labour market. Critical Studies in Education, 58(1), 69-88.

Bourdieu, P. (1990). The Logic of Practice. Stanford University Press.

Braun, V., \& Clarke, V. (2006). Using thematic analysis in psychology. Qualitative research in psychology, 3(2), 77-101.

Byrne, C. (2016). Australia's New Colombo Plan: Enhancing regional soft power through student mobility. International Journal, 71(1), 107-128.

Dai, K., Lingard, B., \& Musofer, R. P. (2020). Mobile Chinese students navigating between fields: (Trans) forming habitus in transnational articulation programmes?. Educational Philosophy and Theory, 52(12), 1329-1340.

Dall'Alba, G., \& Sidhu, R. (2015). Australian undergraduate students on the move: experiencing outbound mobility. Studies in Higher Education, 40(4), 721-744.

Department of Foreign Affairs and Trade. (2020, March, 15). About the New Colombo Plan: What is the New Colombo Plan?. Retrieved from https://www.dfat.gov.au/people-to-people/new-colomboplan/about/Pages/about

Gribble, C., \& Tran, L. (2016). International Trends in Learning Abroad. Universities Australia and IEAA. Retrieved from https://www.researchgate.net

Jones, B. T., Power, A., Gray, T., Downey, G., Hall, T., \& Truong, S. (2016). If you build it, they may not come: Why Australian university students do not take part in outbound mobility experiences. Journal of University Teaching \& Learning Practice, 13(3), 9.

Miles, M. B., Huberman, A. M., \& Saldaña, J. (2014). Qualitative Data Analysis: A Methods Sourcebook. (3rd ed.). Sage Publications. 
Potts, D. (2015). Understanding the early career benefits of learning abroad programs. Journal of Studies in International Education, 19(5), 441-459.

Potts, D. (2016). Outcomes of learning abroad programs. International Education Association of Australia. Retrieved from https://www.ieaa.org.au/documents/item/750

Roy, A., Newman, A., Ellenberger, T., \& Pyman, A. (2019). Outcomes of international student mobility programs: a systematic review and agenda for future research. Studies in Higher Education, 44(9), 1630-1644.

Stake, R. E. (1995). The Art of Case Study Research. Sage Publications.

Tran, L. T. (2016). Mobility as 'becoming': a Bourdieuian analysis of the factors shaping international student mobility. British Journal of Sociology of Education, 37(8), 1268-1289.

Tran, L. T., \& Vu, T. T. P. (2018). Beyond the 'normal' to the 'new possibles': Australian students' experiences in Asia and their roles in making connections with the region via the New Colombo Plan. Higher Education Quarterly, 72(3), 194-207.

Trilokekar, R. D., \& Rasmi, S. (2011). Student perceptions of international education and study abroad: a pilot study at York University, Canada. Intercultural Education, 22(6), 495-511.

UNESCO Institute for Statistics. (2020). Global Flow of Tertiary-Level Students. Retrieved from http://uis.unesco.org/en/uis-student-flow

Wadhwa, R. (2018). International student mobility: theoretical context and empirical evidence from literature. In International Student Mobility and Opportunities for Growth in the Global Marketplace (pp. 15-30). IGI Global. Retrieved from https://www.igiglobal.com/chapter/international-student-mobility/205365

Yin, R. K. (2009). Case Study Research: Design and Methods. (4th ed.). Sage Publications. 